University of Thi-Qar Journal Vol.14 No.1 Mar 2019

Web Site: https://jutq.utq.edu.iq/index.php/main

Email: journal@jutq.utq.edu.iq

\title{
Studying the effect of Metformin and Enzyme inhibitor drags on the level of aromatase Enzyme in the women have hormone disorder the Kirkuk city. https://doi.org/10.32792/utq/utj/vol14/1/6
}

Saria Naji Muhsin

College of Science/ Tikrit University

Email: nada.ahmed@tu.edu.iq

\section{Abstract}

This study included ( 100 ) samples of women used drugs Metformin, enzyme inhibitor in (Azadi General Hospital) (20) blood samples aspirated from healthy women as control sample. The samples were divided into three groups; the first group (40) women used Metformin (have primary infertilits), the second group (40) women used Letrazole (have Secondary infertilits). The third group was the healthy women(control). The results of the study indicated a significant decrease $(\mathrm{p}<0.05)$ in the Activity of Aromatase level in Primary infertile women age groups (18-25), (26-35) and (36-45). the results of this study reveal that three is significant decrease in the Activity of Aromatase $(p<0.05)$ in women who have Secondary infertility with age groups (18-25), (26-35) and (36-45). This Drugs causes decreasing the level of the Estrogen by inhibiting the Aromatase Enzyme . The Drugs also called as (Enzyme inhibitor) because they inhibit Aromatase enzyme, This proves that the Letrazole Drugs has an effective role in stimulating ovulation in women who have primary and secondary infertility.

Keywords: Metformin, enzyme inhibitor, Aromatase Enzyme, Hormones disorder.

\section{Introduction}

\section{Metformin}

Metformin is used to treat high blood sugar levels that are caused by a type of diabetes mellitus or sugar diabetes called type 2 diabetes. With this type of 


\section{University of Thi-Qar Journal Vol.14 No.1 Mar 2019 \\ Web Site: https://jutq.utq.edu.iq/index.php/main \\ Email: journal@jutq.utq.edu.iq}

diabetes, insulin produced by the pancreas is not able to get sugar into the cells of the body where it can work properly. It is also used in the treatment of polycystic ovary syndrome [1]. Metformin is generally well tolerated. Common side effects include diarrhea, nausea and abdominal pain. It has a low risk of causing low blood sugar. High blood lactic acid level is a concern if the medication is prescribed inappropriately[2, 3].

\section{Letrozole}

Is being used commonly as an infertility treatment. Letrozole is a recent addition to the drugs being used for fertility treatment. Fertility drugs are used often in infertility treatments[4]. There are two situations in which fertility drugs may be useful. First, these drugs can be used to induce an egg to develop and be released in women who are not ovulating. This is known as ovulation induction. Fertility drugs can also be used to increase the chances of pregnancy in women who are already ovulating [5].

\section{Aromatase Enzyme}

Aromatase, also called estrogen synthesis, is an enzyme responsible for a key step in the biosynthesis of estrogens. Aromatase is an enzyme found in the liver, responsible for the conversion of the androgens androstenedione and testosterone into the estrogens estrone and estradiol. The aromatase enzyme can be found in many tissues including gonads, brain, adipose tissue, placenta, blood vessels, skin, and bone[6, 7]. In the human, aromatase is expressed in a number of cells, including the ovarian granulosa cell, the placental, the testicular Leydig cell [8].

\section{Location \&Period Of The Study}

The steady has carried out in Azadi General Hospital in Kirkuk governorate from(September 2017) to (February 2018). The steady included(100)patients have hormones disorder ,their ages (18-45) years old. After checking their conditions throughout medical \&clinical tests by specialist doctors in this aspect. As well as choosing random group included (20)Sample of healthy women of age (18-45) years old. Their conditions were checked by specialist doctors in this hospital . The samples divided into three groups :-

*-Group No.1: - included (40) women used Metformin . 


\section{University of Thi-Qar Journal Vol.14 No.1 Mar 2019}

Web Site: https://jutq.utq.edu.iq/index.php/main

Email: journal@jutq.utq.edu.iq

*- Group No.2: - included (40) women used Letrazole .

*- Group No.3: - included (20) healthy women.

\section{Method of Collection the Sample}

100 blood sample Collected from women who have hormones disorder And from healthy women of age (18-45) years old. The blood samples were taken from the vein $.10 \mathrm{~mL}$ from each patient, the blood was put in disposable test tubes . The tubes are empty of (EDTA), After that, The blood was left in room temperature for 20 minutes, The blood was separated by using centrifuge at speed of (3000) rpm for 10 minutes. The serum was extracted by using micropipette ,put $1 \mathrm{~mL}$ of blood serum in disposable tube in order to make( ARO) test

\section{Assay Of Aromatase(ARO) Enzyme}

Aromatase (ARO) enzyme was assay in blood serum depending On (IRMA) (Immunity Radiation Measurement) by Using Kit from Izotop Company , following the instructions of the kit and according to the instruction of the Company who made Elisa machine.

\section{Results and Discussion}

The figures (1),(2),(3) shows the Activity of Aromatase in the women infected with primary infertility treated with " Metformin "(G1) , and infertile women treated with "Letrozole" (G2) compare with control group $(142.6 \pm 13.9 \mathrm{pg} / \mathrm{ml})$ ,(130.8 $\pm 11.46 \mathrm{pg} / \mathrm{ml})$ and $(200.1 \pm 140.6 \mathrm{pg} / \mathrm{ml}) .(140.5 \pm 11.7 \mathrm{pg} / \mathrm{ml}),(129.1 \pm 10.3 \mathrm{pg} / \mathrm{ml})$ and $(203.0 \pm 141.5 \mathrm{p}$ $\mathrm{g} / \mathrm{ml}) .(139.4 \pm 10.6 \mathrm{pg} / \mathrm{ml}), \quad(131.9 \pm 12.5 \mathrm{pg} / \mathrm{ml}) \quad$ and $(201.2 \pm 140.6 \mathrm{pg} / \mathrm{ml})$ respectively. Result revealed a significant decrease $(\mathrm{p}<0.05)$ in the Activity of this enzyme in G1and G2 as compared with the control in the third age group. The results of the study agree with results of $\left[9,1 \cdot, 1{ }^{\prime}\right]$. 
University of Thi-Qar Journal Vol.14 No.1 Mar 2019

Web Site: https://jutq.utq.edu.iq/index.php/main

Email: journal@jutq.utq.edu.iq

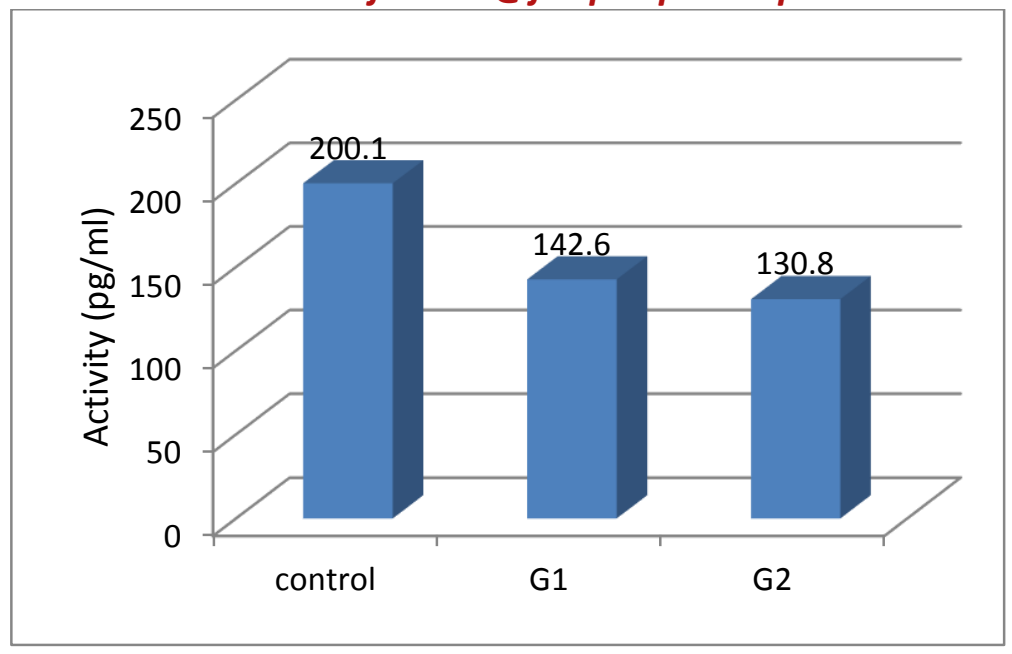

Figure 1: Activity of Aromatase level in Primary infertile women age group (18-25)

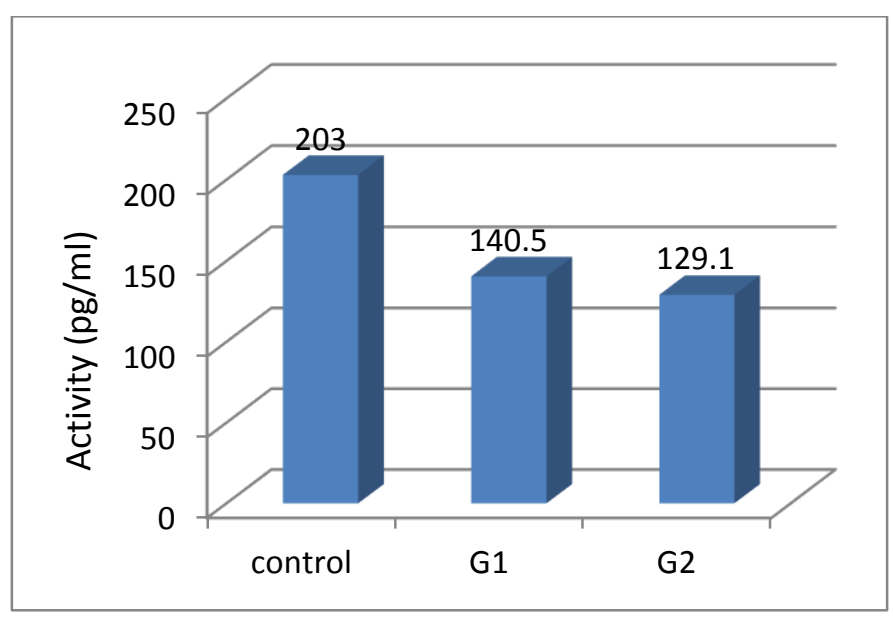

Figure 2: Activity of Aromatase level in Primary infertile women age group (26-35) 


\section{University of Thi-Qar Journal Vol.14 No.1 Mar 2019 \\ Web Site: https://jutq.utq.edu.iq/index.php/main \\ Email: journal@jutq.utq.edu.iq}

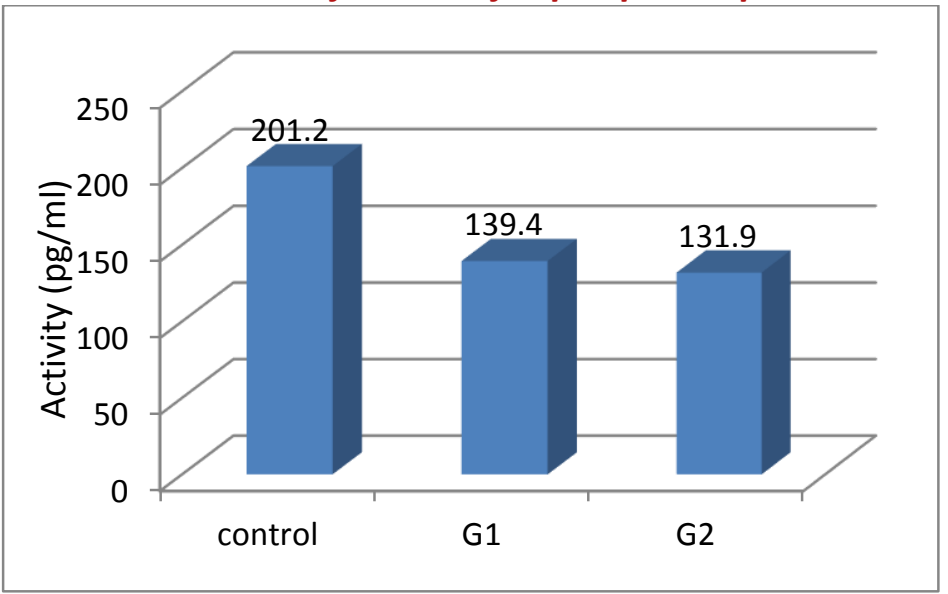

Figure 3: Activity of Aromatase level in Primary infertile women age group (3645)

The figures (4),(5),(6) shows the activity of aromatase in G1and G2 in compare with the( control) group . Results showed a significant decrease in the activity of this Enzyme at level ( $\mathrm{p}<0.05)$ in G1and G2 as compared with the ( control) group in the third age group. The figure (4) included the age group (1825 ), which revealed a significant decrease in the activity of this enzyme between $\mathrm{G} 1(222.4 \pm 134.6 \mathrm{pg} / \mathrm{ml})$, in comparison with control group $(238.4 \pm 150.7$ $\mathrm{pg} / \mathrm{ml})$,and also significant decrease in $\mathrm{G} 2(123.9 \pm 112.36 \mathrm{pg} / \mathrm{ml})$ in comparison with control group, but there is significant rising between G1, in compare with women group G2. The results of the study agree with results of $[7,8]$.

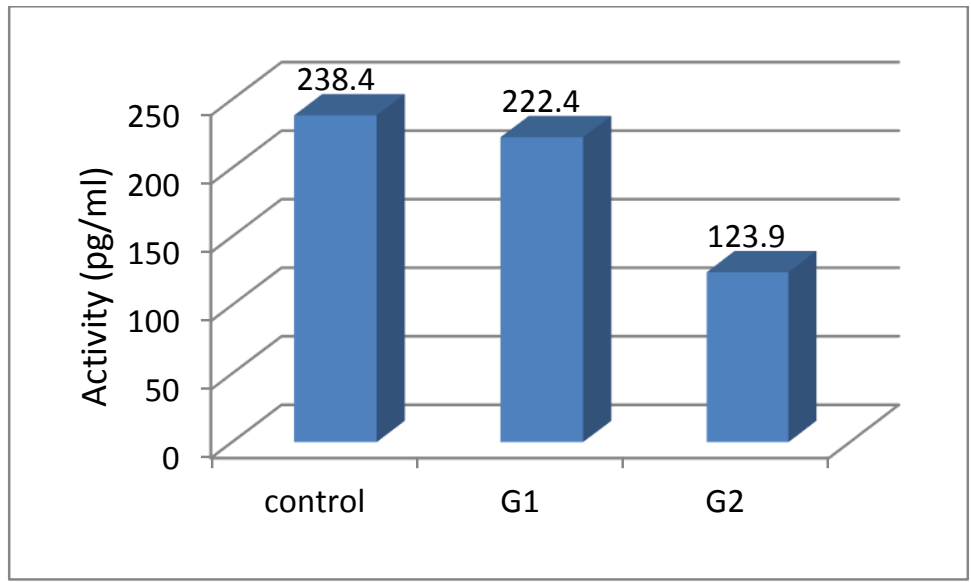




\section{University of Thi-Qar Journal Vol.14 No.1 Mar 2019 \\ Web Site: https://jutq.utq.edu.iq/index.php/main \\ Email: journal@jutq.utq.edu.iq}

Figure 4: Activity of Aromatase level in Secondary infertility women age group $(18-25)$

The figure (5) included the age group (26-35),,which revealed a significant decrease in the activity of this enzyme between $\mathrm{G} 1(221.1 \pm 133.5 \mathrm{pg} / \mathrm{ml})$, in comparison with control group $(230.1 \pm 144.3 \mathrm{pg} / \mathrm{ml})$, and also significant decrease in $\mathrm{G} 2(122.8 \pm 111.31 \mathrm{pg} / \mathrm{ml})$ in comparison with control group, but there is significant rising between G1, in comparison with women group G2. The results of the study agrees with results of [11].

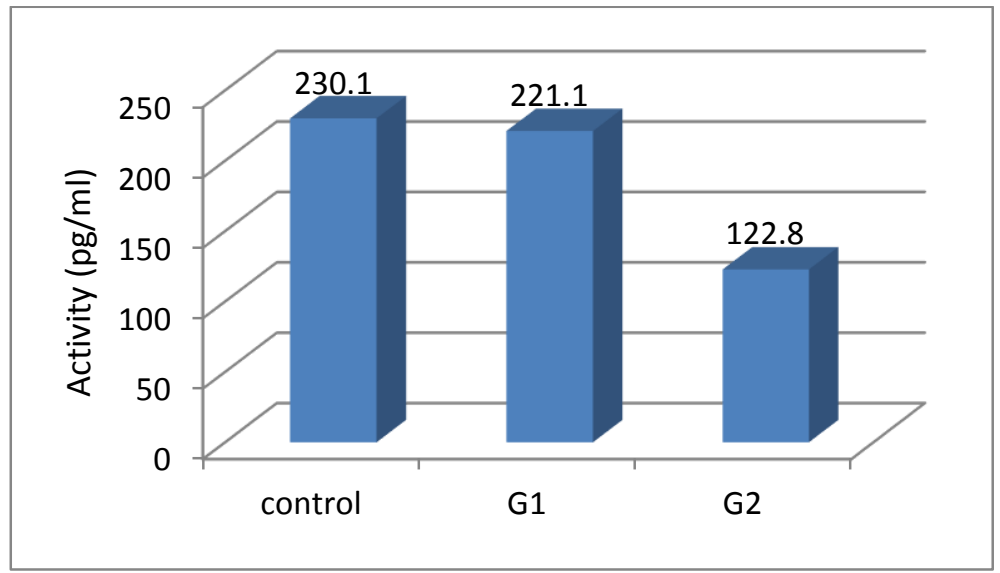

Figure 5: Activity of Aromatase level in Secondary infertile women age group (26-35)

The figure (6) included the age group (36-45),,which revealed a significant decrease in the activity of this enzyme between G1(123.8 $\pm 112.1 \mathrm{pg} / \mathrm{ml})$, in comparison with control group $(222.2 \pm 134.4 \mathrm{pg} / \mathrm{ml})$, and also significant decrease in G2(120.6 $\pm 110.42 \mathrm{pg} / \mathrm{ml})$ in comparison with control group, but there is significant rising between G1, in comparison with women group G2. The results of the study agrees with results of $[6,7]$. 


\section{University of Thi-Qar Journal Vol.14 No.1 Mar 2019 \\ Web Site: https://jutq.utq.edu.iq/index.php/main \\ Email: journal@jutq.utq.edu.iq}

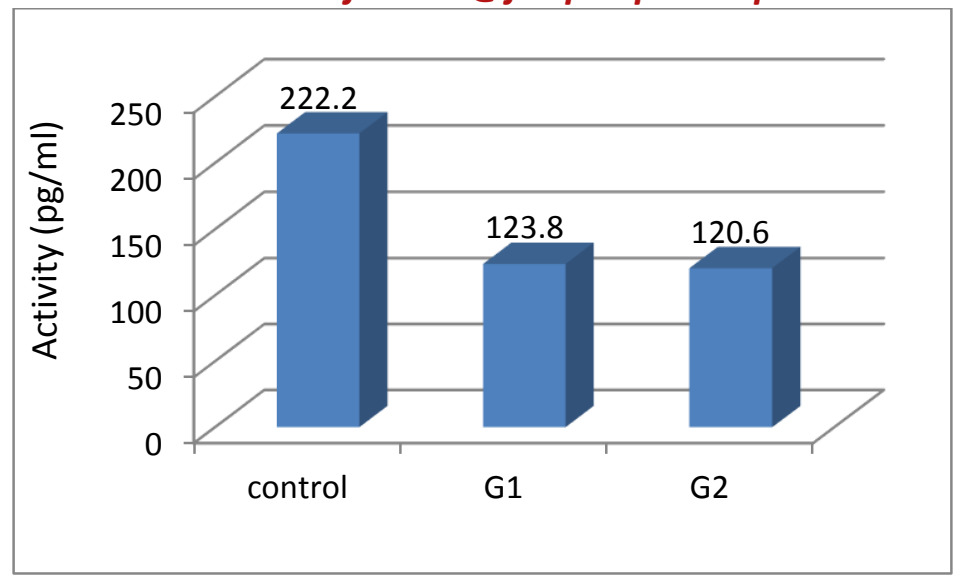

Figure 6: Activity of Aromatase level in Secondary infertile women age group (36-45)

Form these results it was revealed that the changes in Activity of Aromatase is caused by treatment with (Letrozole) medication which it is considered one of the fertility stimulating medication. The medication also called as (Aromatase enzyme inhibitor) because it inhibits aromatase enzyme, The enzyme stimulating FSH ,LH and then activates the ovulation. This medication has higher average of success than the (Metformin) in the women who want to get Pregnant. The success average expectations more than $80 \%$ [11] .This medication causes decreasing the high averages of the estrogen by inhibiting the Aromatase enzyme .This agrees with the results of the researcher [12].and also agrees with [13] and his group from their study the Letrozole medication for group of women infected with breast cancer, the study revealed decreased levels of the estrogen in the women infected who treated with the Letrozole medication. and this agrees with [14]from his study for the women had Breast Cancer which had decreased levels of the estrogen and the decreased levels of the(aromatase enzyme). The aromatase enzyme action on changing the androgen to estrogen in the tissues. This happens mainly in the dipose tissues [15].Also the aromatase enzyme is considered the main source to provide the women by estrogen hormone after the amenorrhea .The medication is used in helping to decrease the estrogen which it is produced by the body, and then stops the cancer cells from proliferation growing [16].From those results, it was revealed that the decrease concentration of this enzyme plays important role in fertility. This agrees with the results of researcher [8].The decrease concentration of this enzyme leads to women fertility, producing ovum ready for 


\section{University of Thi-Qar Journal Vol.14 No.1 Mar 2019 \\ Web Site: https://jutq.utq.edu.iq/index.php/main \\ Email: journal@jutq.utq.edu.iq}

fertilization .The current study showed a high pregnancy average in the women who are unable to ovulate when they treated this medicines .It acts by decreasing Estrogen concentration inhibiting the aromatase enzyme. This agrees with the results of the researcher [17].

\section{Reference}

1-Dunn, CJ; and Peters DH ( 1995). "Metformin. A review of its pharmacological properties and therapeutic use in non-insulin-dependent diabetes mellitus". Drugs. 49 (5): 721-49.

2-Maruthur, NM; Tseng, E; Hutfless, S; Wilson, LM; Suarez-Cuervo, C; Berger, Z; Chu, Y; Iyoha, E; Segal, JB; and Bolen, S (2016). "Diabetes Medications as Monotherapy or Metformin-Based Combination Therapy for Type 2 Diabetes: A Systematic Review and Meta-analysis". Annals of Internal Medicine. 164 (11): 740-51.

3-Malek, M; Aghili, R; Emami, Z; and Khamseh, ME (2013). "Risk of Cancer in Diabetes: The Effect of Metformin" (PDF). ISRN Endocrinology.

4-Ping Zhou, MD;Bina Shah, MD; Kris Prasad, PhD; and Raphael David, MD (2005). "Letrozole Significantly Improves Growth Potential in a Pubertal Boy With Growth Hormone Deficiency". Journal of the American Academy of Pediatrics 115 (2): 245-248.

5-Geneviève ,P; Keith ,J; Ethan ,D;Grober, K; (2009). "Use of the aromatase inhibitor letrozole to treat male infertility". Fertility and Sterility 92 (2): 829.

6-Sebastian S and Bulun SE (2001) A highly complex organization of the regulatory region of the human CYP19 (aromatase) gene revealed by the human genome project. J Clin Endocrinol Metab 86: 4600-4602.

7-Simpson ER, Clyne C, Rubin G, Boon WC, Robertson K, Britt K, Speed C, and Jones M (2002) Aromatase-a brief overview. Annu Rev Physiol 64: 93-127.

8-Simpson ER, Mahendroo MS, Means GD, Kilgore MW, Hinshelwood MM, Graham-Lorence S, Amarneh B, Ito Y, Fisher CR, Michael MD, . (1994) Aromatase cytochrome P450, the enzyme responsible for estrogen biosynthesis. Endocr Rev 15: 342-355. 


\section{University of Thi-Qar Journal Vol.14 No.1 Mar 2019 \\ Web Site: https://jutq.utq.edu.iq/index.php/main \\ Email: journal@jutq.utq.edu.iq}

(9)Ghosh D, Griswold J, Erman M, Pangborn W (2009). "Structural basis for androgen specificity and oestrogen synthesis in human aromatase". Nature 457 (7226): 219-23.

( '•)Simpson ER, Mahendroo MS, Means GD, Kilgore MW, Hinshelwood MM, Graham-Lorence S, Amarneh B, Ito Y, Fisher CR, Michael MD, et al. (1994) Aromatase cytochrome P450, the enzyme responsible for estrogen biosynthesis. Endocr Rev 15: 342-355.

(1) Duffy TA, Picha ME, Won ET, Borski RJ, McElroy AE, Conover DO (2010). "Ontogenesis of gonadal aromatase gene expression in atlantic silverside (Menidia menidia) populations with genetic and temperature-dependent sex determination". J Exp Zool A Ecol Genet Physiol 313 (7): 421-31.

12- Tulandi T, Martin J, Al-Fadhli R, et al. (2006). "Congenital malformations among 911 newborns conceived after infertility treatment with letrozole or clomiphene citrate". Fertility and Sterility 85 (6): 1761-5.

13- Rose C, Vtoraya O, Plyzanska A, 2002. Letrozole (Femara) anastrozole (Arimidex): second-line treatment in postmenopausal women with advanced breast cancer. Proc Annu Meet Am Soc Clin Oncol.:131.

14- ENG, E.T. 2001. Suppression of aromatase (estrogen synthetase) by red wine photochemical. Breast Cancer Res. Treat. 67: 133-146.

15- Sinha, Kounteya (2011). "Finally, expert panel bans fertility drug Letrozole". The Times of India. Retrieved 14 November 2011.

16- Santen, R. J.; Brodie, H.; Simpson, E. R.; Siiteri, P. K.; Brodie, A. (2009). "History of Aromatase: Saga of an Important Biological Mediator and Therapeutic Target". Endocrine Reviews 30 (4): 343-375.

17- Ghosh D, Griswold J, Erman M, Pangborn W (2009). "Structural basis for androgen specificity and oestrogen synthesis in human aromatase". Nature 457 (7226): 219-23. 
University of Thi-Qar Journal Vol.14 No.1 Mar 2019

Web Site: https://jutq.utq.edu.iq/index.php/main

Email: journal@jutq.utq.edu.iq

دراسة تأثير عقار Metformin و مثبط الإنزيم على مستويات إنزيم

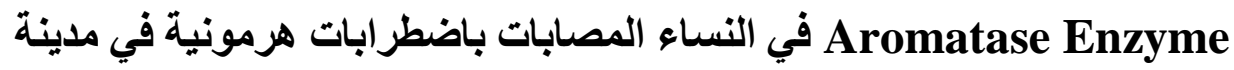

$$
\text { كركوك. }
$$

ساريا ناجي محسن

كلية العلوم / جامعة تكريت

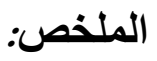

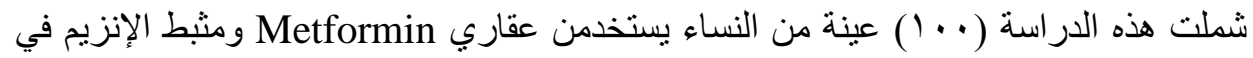

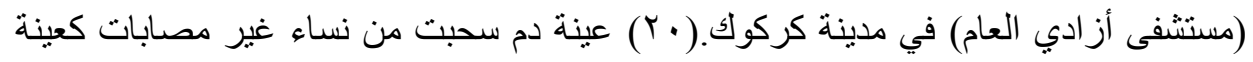

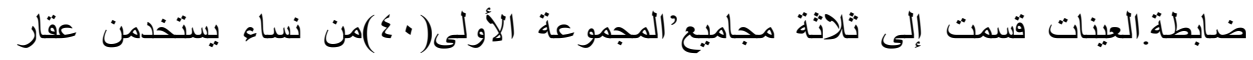
Metformin

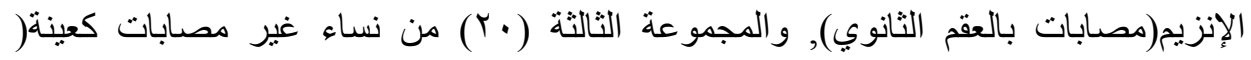

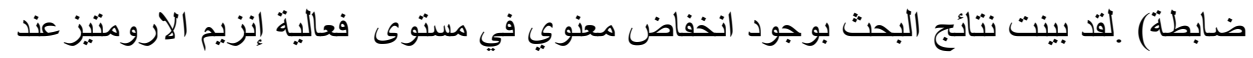

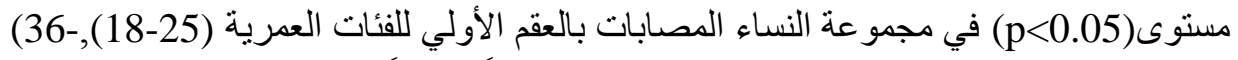

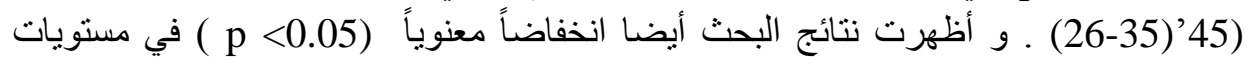

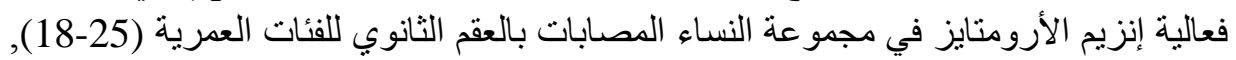

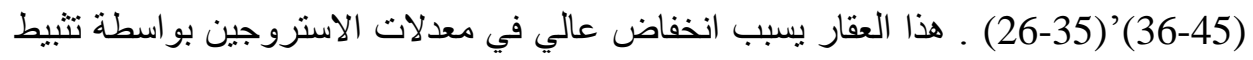

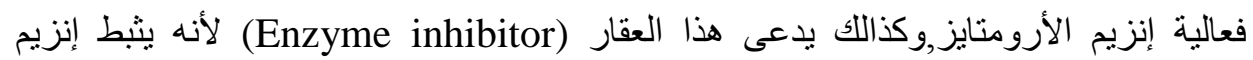

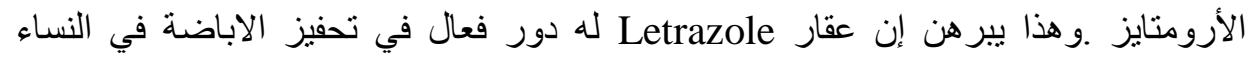

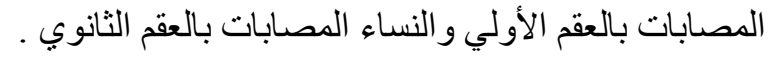

